Endocrine Journal 1996, 43 (1), 109-114

Note

\title{
Absence of Mutations at Codon 768 of the RET Proto- Oncogene in Sporadic and Hereditary Pheochromocytomas
}

\author{
KATSUHIKO YOSHIMOTO, TAKEHIKO KIMURA*, CHISATO TANAKA, \\ MAKI MORITANI, HIROYUKI IWAHANA, AND MITSUO ITAKURA \\ Otsuka Department of Clinical and Molecular Nutrition and *First Department of Internal Medicine, \\ School of Medicine, The University of Tokushima, Tokushima 770, Japan
}

\begin{abstract}
Sixteen sporadic pheochromocytomas, 3 pheochromocytomas in neurofibromatosis 1 , and 4 pheochromocytomas in multiple endocrine neoplasia (MEN) 2A or 2B were screened for mutations at codon 768 of the RET proto-oncogene by AluI digestion of polymerase chain reaction (PCR) products and mutations in exon 13 by PCR-single strand conformation polymorphism (SSCP) analysis. Although mutations at codon $768(\mathrm{GAG} \rightarrow \mathrm{GAC} ; \mathrm{Glu} \rightarrow \mathrm{Asp})$ of the $R E T$ proto-oncogene were recently reported to be found in $40 \%$ of sporadic medullary thyroid carcinomas (MTCs), the absence of missense mutations at codon 768 was confirmed both with PCR-restriction fragment length polymorphism (RFLP) and PCRSSCP analysis in all examined cases of pheochromocytomas. These results suggest that mutations at codon 768 of the RET proto-oncogene do not represent a frequent mechanism of tumorigenesis for both sporadic and hereditary pheochromocytomas.
\end{abstract}

Key words: RET proto-oncogene, Mutation, Codon 768, Exon 13, Pheochromocytoma

(Endocrine Journal 43: 109-114, 1996)

THE RET proto-oncogene encodes a protein structurally related to transmembrane receptors with cytoplasmic tyrosine-kinase domains [1]. The RET protein spans the cell membrane, and is involved in the inward transduction of transmembrane signals. The protein has three regions: an extracellular portion which interacts with ligands; a transmembrane region; and a cytoplasmic tyrosine kinase region.

The predisposing genes for MEN 2A, familial thyroid medullary carcinoma (FMTC) and MEN 2B have been shown to be assigned to the RET proto-oncogene $[2,3]$. Recently, germline mutations of the RET proto-oncogene have been described in patients affected with MEN 2A, FMTC or MEN 2B [2-7]. In families with MEN 2A or

Received: June 12, 1995

Accepted: August 3, 1995

Correspondence to: Dr. Mitsuo ITAKURA, Otsuka Department of Clinical and Molecular Nutrition, School of Medicine, The University of Tokushima, 3-18-15 Kuramoto-cho, Tokushima 770, Japan
FMTC, detected mutations affect one of five cysteine residues in the extracellular region adjacent to the transmembrane segment of the RET protein $[2,4,5]$. In MEN 2B, a mutation at codon 918 causing the substitution of threonine for methionine of the tyrosine kinase domain of the RET protein was detected in almost every case $[3,6,7]$.

A missense mutation at codon 768 in the tyrosine kinase domain of the RET proto-oncogene was recently described in a family with FMTC, which does not have a cysteine codon mutation [8]. The same mutation was also detected in $40 \%$ of sporadic MTCs which do not have codon 918 mutations. With respect to sporadic pheochromocytomas, we detected codon 918 mutations in $31 \%$ of sporadic pheochromocytomas [9]. In the present study, we analyzed sporadic pheochromocytomas and pheochromocytomas with neurofibromatosis 1 (NF1), MEN 2A, or MEN 2B for mutations of codon 768 of the RET proto-oncogene. 
Table 1. A list of analyzed cases

\begin{tabular}{|c|c|c|c|c|c|}
\hline No. & Age & sex & Type & Tumors analyzed & $\begin{array}{l}\text { Location, size } \\
\text { and weight }\end{array}$ \\
\hline 1. & 50 & $\mathrm{M}$ & sporadic & pheochromocytoma & right $(4.3 \times 5.4 \mathrm{~cm})$ \\
\hline 2. & 47 & $\mathrm{~F}$ & sporadic & pheochromocytoma & left $(7 \times 5 \times 3.5 \mathrm{~cm}, 50 \mathrm{~g})$ \\
\hline 3. & 51 & $\mathrm{~F}$ & sporadic & pheochromocytoma & right $(4.3 \times 5.4 \mathrm{~cm})$ \\
\hline 4. & 53 & $\mathrm{~F}$ & sporadic & pheochromocytoma & left $(5 \times 5 \mathrm{~cm})$ \\
\hline 5. & 48 & $\mathrm{M}$ & sporadic & pheochromocytoma & left $(3 \times 3 \mathrm{~cm})$ \\
\hline 6. & 69 & $\mathrm{~F}$ & sporadic & pheochromocytoma & left $(32.2 \mathrm{~g})$ \\
\hline 7. & 70 & $\mathrm{~F}$ & sporadic & pheochromocytoma & right $(3 \times 3 \mathrm{~cm})$ \\
\hline 8. & 42 & $\mathrm{~F}$ & sporadic & pheochromocytoma & right (?) \\
\hline 9. & 19 & $M$ & sporadic & pheochromocytoma & right (?) \\
\hline 10. & 23 & $\mathrm{~F}$ & sporadic & pheochromocytoma & $?$ \\
\hline 11. & 64 & $\mathrm{~F}$ & sporadic & pheochromocytoma & right $(68 \mathrm{~g})$ \\
\hline 12. & $?$ & $\mathrm{~F}$ & sporadic & pheochromocytoma & $?$ \\
\hline 13. & 41 & $\mathrm{~F}$ & sporadic & pheochromocytoma & right $(3 \times 4 \mathrm{~cm})$ \\
\hline 14. & 60 & $\mathrm{M}$ & sporadic & pheochromocytoma & right $(6.5 \times 5.3 \times 3.7 \mathrm{~cm})$ \\
\hline 15. & 45 & $\mathrm{~F}$ & sporadic & pheochromocytoma & right $(5 \times 6 \mathrm{~cm})$ \\
\hline 16. & 45 & $\mathrm{~F}$ & sporadic & $\begin{array}{l}\text { pheochromocytoma } \\
\text { (malignant) }\end{array}$ & left $(5.3 \times 5.0 \times 4.7 \mathrm{~cm})$ \\
\hline 17. & 44 & $\mathrm{~F}$ & NF1 & pheochromocytoma & left $(7 \times 6 \times 5 \mathrm{~cm})$ \\
\hline 18. & 19 & $\mathrm{~F}$ & NF1 & pheochromocytoma & left $(5 \times 4 \times 3 \mathrm{~cm})$ \\
\hline 19. & 34 & $\mathrm{M}$ & NF1 & pheochromocytoma & left $(9 \times 7.2 \times 6.5 \mathrm{~cm})$ \\
\hline 20. & 32 & M & MEN 2A & pheochromocytoma & $\begin{array}{r}\text { bilateral right }(1.8 \times 1.6 \times 0.8 \mathrm{~cm}) \\
\text { left }(2.9 \times 2.6 \times 1.7 \mathrm{~cm})\end{array}$ \\
\hline 21. & 25 & $\mathrm{~F}$ & MEN 2A & pheochromocytoma & $\begin{array}{c}\text { bilateral right }(8.2 \times 7.1 \times 5.8 \mathrm{~cm}) \\
\text { left }(0.5 \times 0.4 \mathrm{~cm})\end{array}$ \\
\hline 22. & 46 & $\mathrm{~F}$ & NEM $2 A$ & pheochromocytoma & $\begin{array}{c}\text { bilateral right }(460 \mathrm{~g}) \\
\text { left }(20 \mathrm{~g})\end{array}$ \\
\hline 23. & 18 & $\mathrm{~F}$ & MEN 2B & pheochromocytoma & $\begin{array}{l}\text { bilateral right }(26.5 \mathrm{~g}) \\
\text { left }(12.5 \mathrm{~g})\end{array}$ \\
\hline
\end{tabular}

?: information unavailable.

\section{Materials and Methods}

\section{Tissue samples}

Tissue samples were obtained at surgical operations or from paraffin-embedded sections. The diagnosis of pheochromocytoma was confirmed by histological examinations of the tumors. Peripheral blood samples were collected at surgical operations or retrospectively. These included 16 patients with sporadic pheochromocytomas, 3 NF1 patients with pheochromocytomas, 3 MEN 2A patients, and $1 \mathrm{MEN} 2 \mathrm{~B}$ patient. The sporadic tumors were considered sporadic because patients did not have a family history suggestive of MEN 2A, MEN 2B, NF1 or von Hippel-Lindau syndrome. The clinical data are listed in Table 1.

\section{Extraction of DNA from tissues}

DNA was isolated from frozen tumor sections obtained at surgical operations, leukocytes and paraffin-embedded specimen, as previously described [10].

\section{PCR amplification and mutation analysis}

For PCR-RFLP of codon 768, genomic DNA was amplified with primers oRB1395 (5'-TCCAGGAGCGATCGTTTGCA-3') and oRB1396 (5'-GACATGTGGGTGGTTGACCT-3'). The PCR amplified a 121 bp fragment containing a part of exon 13 of the RET proto-oncogene. PCR was performed in a 10 $\mu l$ reaction mixture containing $0.1 \mu \mathrm{g}$ of genomic DNA, $200 \mu \mathrm{M}$ each of deoxynucleotide triphosphate, $10 \mathrm{mM}$ Tris- $\mathrm{HCl}, \mathrm{pH} 8.3,1.5 \mathrm{mM} \mathrm{MgCl}_{2}, 50$ 
$\mathrm{mM} \mathrm{KCl}, 10$ pmol of PCR primers, and 0.25 unit of Taq DNA polymerase. The reaction was carried out in a Program Temp Control System PC-700 (ASTEC, Fukuoka, Japan) for 30 cycles at $94^{\circ} \mathrm{C}$ for $1 \mathrm{~min}, 60^{\circ} \mathrm{C}$ for $1 \mathrm{~min}$, and $72^{\circ} \mathrm{C}$ for $2 \mathrm{~min}$. The products were digested with $A l u \mathrm{I}$ according to the manufacturer's recommendations (Takara Shuzo, Kyoto, Japan) and electrophoresed on a $10 \%$ polyacrylamide gel, followed by ethidium bromide staining. The gels were photographed with an ultraviolet transilluminator.

For PCR-SSCP analysis of exon 13, a pair of intron-based primers, [oRB1395 (5'-TTCCAGGAGCGATCGTTTGCA-3') and oRB1508 (5'-GGAGAACAGGGCTGTATGGA-3')] were used to generate a $223 \mathrm{bp}$ PCR product including exon 13 . PCR was performed with $50 \mathrm{ng}$ of genomic DNA in a total volume of $5 \mu l$ containing $0.5 \mu l$ of $[\alpha-$ $\left.{ }^{32} \mathrm{P}\right] \mathrm{dCTP}(3000 \mathrm{Ci} / \mathrm{mmol} ; 10 \mathrm{mCi} / \mathrm{ml})$. Thirty cycles consisting of $1 \mathrm{~min}$ at $94^{\circ} \mathrm{C}, 1 \mathrm{~min}$ at $60^{\circ} \mathrm{C}$ and $2 \mathrm{~min}$ at $72{ }^{\circ} \mathrm{C}$ were performed. The electrophoresis and exposure to $\mathrm{X}$-ray films were performed as described previously [10].

\section{Results}

Genomic DNAs obtained from pheochromocytomas were tested for codon 768 mutations of the RET proto-oncogene by AluI digestion of PCR products. Because the mutation of codon 768 (GAG $\rightarrow$ GAC; Glu $\rightarrow$ Asp) causes loss of an AluI restriction site, $A l u \mathrm{I}$ restriction digestion was performed for exon 13 amplicons. No mutations causing loss of $A l u \mathrm{I}$ restriction site at codon 768 were detected in 16 sporadic pheochromocytomas, 3 pheochromocytomas with NF1, 3 pheochromocytomas with MEN 2A or 1 pheochromocytoma with MEN 2B (Fig. 1).

PCR-SSCP analysis of exon 13 from genomic DNA of pheochromocytomas showed 3 different patterns (Fig. 2). The difference of mobility was found to be caused by polymorphic nucleotide changes at codon 769 (data not shown) [11]. No extra bands except those caused by polymorphism were detected in all examined tumors.

In Figs. 1 and 2, representative results are shown for sporadic pheochromocytomas (case 1 to 9 in Table 1) and pheochromocytomas with NF1 (case 17 in Table 1) or MEN 2A (case 20 in Table 1). Results for other cases are omitted because the re-

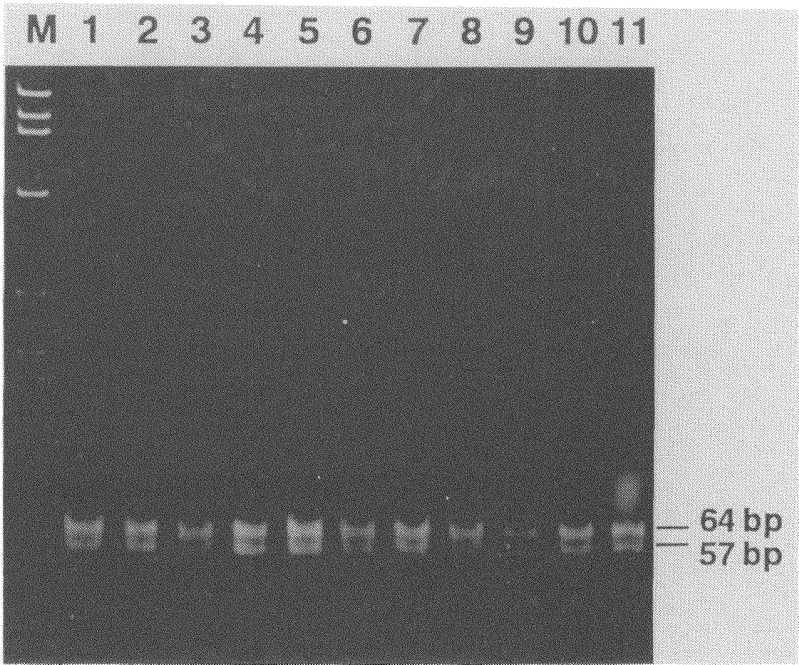

Fig. 1. AluI restriction digestion of exon 13 of the RET proto-oncogene for pheochromocytomas. Genomic DNAs from sporadic pheochromocytomas and pheochromocytomas with NF1 or MEN 2A were amplified by PCR with primers for exon 13 of the RET proto-oncogene. Products $121 \mathrm{bp}$ in size were cleaved with $A l u \mathrm{I}$, size-fractionated by electrophoresis through a $10 \%$ polyacrylamide gel and stained with ethidium bromide. M, øX174 HaeIII-digested DNA fragments used as molecular markers; lanes 1-9, sporadic pheochromocytomas (cases 1 to 9 in Table 1); lane 10, pheochromocytoma with NF1 (case 17 in Table 1); lane 11, pheochromocytoma with MEN 2A (case 20 in Table 1). Lanes 1-11 revealed no point mutations causing loss of AluI restriction site at codon 768 .

sults are the same as those in Figs. 1 and 2.

To avoid possible false-negative results from PCR-RFLP and PCR-SSCP analysis, DNA from several tumors was subcloned into plasmid vectors and sequenced. DNA sequencing showed no mutations in exon 13 of the RET proto-oncogene in these tumors (data not shown).

\section{Discussion}

Missense mutations in the $R E T$ proto-oncogene have been found in the constitutional DNA of the majority of patients with MEN 2A, FMTC, or MEN 2B [2-7]. In MEN 2A and FMTC, the mutations alter 1 of 5 cysteine residues in exon 10 and 11 within the cysteine-rich domain of the RET protooncogene. These mutations induced ligandindependent dimerization of the RET protein, leading to activation of tyrosine kinase [12, 13]. In 


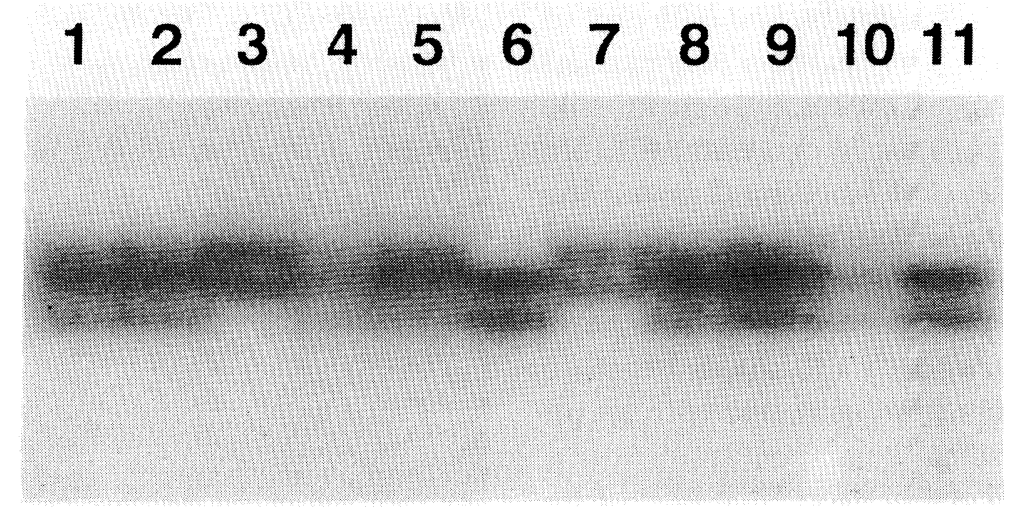

Fig. 2. PCR-SSCP analysis of exon 13 of the RET proto-oncogene. Electrophoresis was performed in a 5\% polyacrylamide gel with $5 \%$ glycerol at room temperature. Lanes $1-9$, sporadic pheochromocytomas (cases 1 to 9 in Table 1); lane 10, pheochromocytoma with NF1 (case 17 in Table 1); lane 11, pheochromocytoma with MEN 2A (case 20 in Table 1). Three different polymorphic patterns are shown: lanes 3 and 7, CTT at codon 769; lanes 6, 10, and 11, CTG at codon 769; lanes 1, 2, 4, 5, 8, and 9, heterozygous for both alleles. Lanes 1-11 revealed no extra bands except those caused by polymorphism in exon 13 .

patients with MEN 2B, a single missense mutation affecting a methionine (ATG) to threonine (ACG) change at codon 918 has been found. The codon 918 mutation altered RET catalytic properties both quantitatively and qualitatively, and resulted in constitutive activation of tyrosine kinase [12].

Although MTC and pheochromocytomas are component tumors of the MEN 2 syndromes, they also occur as sporadic types. By analogy applied to other inherited cancer syndromes, somatic mutations corresponding to germline mutations were observed in MEN 2A, FMTC and MEN 2B. In sporadic MTC, 23-40\% had codon 918 mutations $[3,14,15]$, but mutations in the cysteine-rich region were rare $[4,16]$. Recently, a missense mutation at codon 768 in the tyrosine kinase domain of the RET proto-oncogene was also detected in $40 \%$ of sporadic MTCs which do not have codon 918 mutations [8]. In sporadic pheochromocytomas, no mutations except 1 mutation at codon 609 and 2 mutations at codon 620 in the cysteine-rich region have been reported [4, 7, 17]. Although Lindor et al. [17] reported a 6bp-deletion at codons 632 and 633 and a mutation at codon 925 in sporadic pheochromocytomas, the significance of these mutations in tumorigenesis of pheochromocytomas is unclear. We also found no mutations in the cysteine-rich region in 12 sporadic pheochromocy- tomas and 3 pheochromocytomas with NF1 [16]. Recently, we found codon 918 mutations in $31 \%$ of sporadic pheochromocytomas (cases 13-16 in Table 1 in this study), for which mutations were heterozygous and tumor-specific [9]. In this study, codon 768 mutations were shown to be rare in sporadic pheochromocytomas in contrast to sporadic MTCs. In addition, pheochromocytomas with NF1 and MEN 2A/2B were shown to have no mutations at codon 768 .

Codon 768 was located in the subdomain III implicated in ATP binding within the tyrosine kinase domain of RET protein. The mutation of codon 768 from glutamine to aspartic acid would affect both substrate interactions and ATP-receptor binding [8]. Results obtained by Eng et al. [8] showed that the somatic mutation at codon 768 contributed to tumorigenesis of thyroid C-cells. The reason for the difference between the frequency of mutations at codon 768 in sporadic MTCs and pheochromocytomas was unknown. But all patients with MEN 2A and 2B develop MTCs, and approximately $50 \%$ of patients develop pheochromocytomas [18]. These results suggest that mutations of the RET proto-oncogene are not sufficient, and other genetic changes are required in the tumorigenesis of pheochromocytomas. This situation may be applicable to sporadic MTCs and 
pheochromocytomas. In addition, it is possible that the frequency of MTCs and pheochromocytomas may also depend on the number of RET-positive cells and expression levels of RET protein in thyroid C-cells and adrenal chromaffin cells [19]. In future, the study on transgenic mice carrying the mutated RET proto-oncogene at codon 768 with tissue-specific promoters should provide further insight into the role of the RET proto-oncogene in the development of sporadic MTCs and pheochromocytomas.

\section{Acknowledgments}

The authors thank Dr. Akira Miyauchi for providing tumors. We are grateful to Professors Shiro Saito and Toshiaki Sano for continuous support. This work was supported in part by a Grant-inAid for Scientific Research from the Ministry of Education, Science and Culture of Japan and by a grant from Otsuka Pharmaceutical Factory, Inc., for Otsuka Department of Clinical and Molecular Nutrition, School of Medicine, The University of Tokushima.

\section{References}

1. Takahashi M, Buma $Y$, Iwamoto $T$, Inaguma $Y$, Ikeda H, Hiai H (1988) Cloning and expression of the ret proto-oncogene encoding a tyrosine kinase with two potential transmembrane domains. Oncogene 3: 571-578.

2. Mulligan LM, Kwok JBJ, Healey CS, Elsdon MJ, Eng C, Gardner E, Love DR, Mole SE, Moore JK, Papi L, Ponder MA, Telenius H, Tunnacliffe A, Ponder BAJ (1993) Germline mutations of the RET proto-oncogene in multiple endocrine neoplasia type 2A. Nature 363: 458-460.

3. Hofstra RMW, Landsvater RM, Ceccherini I, Stulp RP, Stelwagen T, Luo Y, Pasini B, Hoppener JWM, van Amstel HKP, Romeo G, Lips CJM, Buys CHC (1994) A mutation in the RET proto-oncogene associated with multiple endocrine neoplasia type $2 \mathrm{~B}$ and sporadic medullary thyroid carcinoma. Nature 367: 375-376.

4. Donis-Keller H, Dou S, Chi D, Carlson KM, Toshima K, Lairmore TC, Howe JR, Moley JF, Goodfellow PJ, Wells SA Jr (1993) Mutations in the RET protooncogene are associated with MEN 2A and FMTC. Hum Mol Genet 2: 851-865.

5. Mulligan LM, Eng C, Healey CS, Clayton D, Kwok JBJ, Gardner E, Ponder MA, Frilling A, Jackson CE, Lehnert H, Neuman HPH, Thibodeau SN, Ponder BAJ (1993) Specific mutations of the RET protooncogene are related to disease phenotype in MEN 2A and FMTC. Nature Genet 6: 70-74.

6. Carlson KM, Dou S, Chi D, Scavarda N, Toshima $\mathrm{K}$, Jackson CE, Wells SA Jr, Goodfellow PJ, DonisKeller H (1994) Single missense mutation in the tyrosine kinase catalytic domain of the RET protooncogene is associated with multiple endocrine neoplasia type 2B. Proc Natl Acad Sci USA 91: 15791583.

7. Eng C, Smith DP, Mulligan LM, Nagai MA, Healey
CS, Ponder MA, Gardner E, Scheumann GFW, Jackson CE, Tunnacliffe A, Ponder BAJ (1994) Point mutations within the tyrosine kinase domain of the $R E T$ proto-oncogene in multiple endocrine neoplasia type $2 \mathrm{~B}$ and related sporadic tumours. Hum Mol Genet 3: 237-241.

8. Eng C, Smith DP, Mulligan LM, Healey CS, Zvelebil MJ, Stonehouse TJ, Ponder MA, Jackson CE, Waterfield MD, Ponder BAJ (1995) A novel point mutation in the tyrosine kinase domain of the $R E T$ proto-oncogene in sporadic medullary thyroid carcinoma and in a family with FMTC. Oncogene 10: 509-513.

9. Yoshimoto K, Tanaka C, Hamaguchi S, Kimura T, Iwahana H, Miyauchi A, Itakura M (1995) Tumor specific mutations in the tyrosine kinase domain of the RET proto-oncogene in pheochromocytomas of sporadic type. Endocrine J 42: 265-270.

10. Yoshimoto K, Iwahana H, Fukuda A, Sano T, Saito S, Itakura M (1992) Role of p53 mutations in endocrine tumorigenesis: Mutation detection by polymerase chain reaction-single strand conformation polymorphism. Cancer Res 52: 5061-5064.

11. Ceccherini I, Hofstra RMW, Luo Y, Stulp RP, Barone V, Stelwagen T, Bocciardi R, Nijveen H, Bolino A, Seri M, Ronchetto P, Pasini B, Bozzano M, Buys CHCM, Romeo G (1994) DNA polymorphisms and conditions for SSCP analysis of the 20 exons of the ret proto-oncogene. Oncogene 9: 3025-3029.

12. Santro M, Carlomagno F, Romano A, Bottaro DP, Dathan NA, Grieco M, Fusco A, Vecchio G, Matoskova B, Kraus MH, Di Fiore PP (1995) Activation of $R E T$ as a dominant transforming gene by germline mutations of MEN2A and MEN2B. Science 267: 381-383.

13. Asai N, Iwashita T, Matsuyama M, Takahashi M (1995) Mechanism of activation of the ret proto- 
oncogene by multiple endocrine neoplasia 2A mutations. Mol Cell Biol 15: 1613-1619.

14. Blaugrund JE, Johns MM, Eby YJ, Ball DW, Baylin SB, Hruban RH, Sidransky D (1994) RET protooncogene mutations in inherited and sporadic medullary thyroid cancer. Hum Mol Genet 3: 18951897.

15. Eng C, Mulligan LM, Smith DP, Healey CS, Frilling A, Raue S, Neumann HPH, Pfagner R, Behmel A, Lorenzo MJ, Stonehouse TJ, Ponder MA, Ponder BAJ (1995) Mutation of the RET protooncogene in sporadic medullary thyroid carcinoma. Genes, Chromosomes $\mathcal{E}$ Cancer 12: 209-212.

16. Kimura T, Yoshimoto K, Yokogoshi Y, Saito S (1995) Mutations in the cysteine-rich region of the RET proto-oncogene in patients diagnosed as having sporadic medullary thyroid carcinoma. Endocrine J 42: 517-525.

17. Lindor NM, Honchel R, Khosla S, Thibodeau SN (1995) Mutations in the RET protooncogene in sporadic pheochromocytomas. J Clin Endocrinol Metab 80: 627-629.

18. Wells SA Jr, Donis-Keller H (1994) Current perspectives on the diagnosis and management of patients with multiple endocrine neoplasia type 2 syndromes. Endocrinol Metab Clin North Am 23: 215-228.

19. Tsuzuki T, Takahashi M, Asai N, Iwashita T, Matsuyama M, Asai J (1995) Spatial and temporal expression of the ret proto-oncogene product in embryonic, infant and adult rat tissues. Oncogene 10: 191-198. 